\title{
A VEVÖI ÉRTÉK ALAKULÁSA EGY HOSSZÚ ÉLETTARTAMÚ TERMÉK TERMELÉSI-SZOLGÁLTATÁSI ÉRTÉKLÁNCÁBAN
}

\section{ANALYZING CUSTOMER VALUE IN THE PRODUCT- SERVICE VALUE CHAIN OF A DURABLE PRODUCT}

\author{
Kalló Noémi ${ }^{1}$, Gerse-Krizsa Teréz ${ }^{1 *}$ \\ ${ }^{1}$ Menedzsment és Vállalkozásgazdaságtan Tanszék, Gazdaság- és Társadalomtudományi Kar, Budapesti \\ Műszaki és Gazdaságtudományi Egyetem, Magyarország \\ https://doi.org/10.47833/2021.1.ECO.001
}

\section{Kulcsszavak: \\ Vevői érték \\ Értéklánc \\ Minőségmenedzsment}

\section{Keywords:}

Customer value

Value chain

Quality management

\section{Cikktörténet:}

Beérkezett 2021. március 10.

Átdolgozva 2021. március 22.

Elfogadva 2021. április 3.

\begin{abstract}
Összefoglalás
Napjaink értékláncai jellemzően egyaránt tartalmaznak gyártói és szolgáltatói tevékenységeket. Az ilyen termelési-szolgáltatási értékláncok vizsgálata egyszerre követeli meg az általános folyamatvizsgálatot, a termelés sajátosságainak figyelembevételét és a szolgáltatások egyedi jellemzőinek szem előtt tartását. A bemutatott vizsgálat célja a hosszú élettartamú (épitőanyag-ipari) termékek értékláncának felvázolása, a folyamat szereplőinek (elsősorban vevőinek) azonosítása és a folyamatban zajló értékteremtés feltárása. Az értékteremtés fejlesztése érdekében fontos azonosítani, hogy a folyamatban meddig elegendő termékminőségben gondolkozni és hol kerülnek előtérbe a szolgáltatáshoz kapcsolódó dimenziók, szolgáltatáselemek, illetve hogy az egyes folyamatlépésekben milyen fejlesztési lehetöségek rejlenek.
\end{abstract}

\begin{abstract}
Today's value chains typically include both manufacturing and service activities. Examining such production-service value chains simultaneously requires a general process analysis, consideration of the specifics of production, and consideration of the unique characteristics of the services. The aim of the study is to outline the value chain of long-lived (building materials industry) products, to review the production and use process, and to explore the value creation that takes place in the process. In order to improve value creation, it is important to identify how long it is enough to think in product quality in the process and where the dimensions and service elements related to the service come to the fore, and what development opportunities lie in each process step.
\end{abstract}

\footnotetext{
* Kapcsolattartó szerző: Gerse-Krizsa Teréz Tel.: +36 205229044

E-mail cím: krizsa@mvt.bme.hu
} 


\section{Bevezetés}

Az értékteremtés gondolata a vállalatok és tudományos élet számos területén fókuszba került az elmúlt évtizedekben. Vevői értékről beszél például a marketingmenedzsment értékvezérelt marketingkoncepciója [1], a minőségmenedzsment a minőség definíciója kapcsán [7] vagy épp a lean menedzsment a maga alapelvei között [14].

A vevői érték növelése érdekében a vállalatok nem csak hogy értékláncokban és vállalatokon átívelő ellátási láncokban [2] [12] gondolkoznak, de sok esetben bővítik tevékenységi körüket vagy legalábbis elfogadják, hogy a tevékenységük általi értékteremtés nem áll meg a vállalatuk határainál. Az integrált termék-szolgáltatás rendszereknek (Product Service Systems, PSS) - orientációjuk szerinti bontásban - több fajtáját különböztetjük meg [3] [9]. Típusuktól függetlenül azonban kivétel nélkül igaz ezekre a rendszerekre, hogy az értéklánc e kettős - termék és szolgáltatás jellemzőket hordozó - tulajdonságából és a láncban résztvevők nagyobb számából adódóan az értékteremtés folyamata, elvárásai és mérési lehetőségei is igen sokszínű kihívások elé álítja a szakembereket.

Vizsgálataink során ilyen jellemzőkkel bíró termékek értékláncát, értékteremtés folyamatát és a vevői elégedettséget befolyásoló tényezőket vizsgáljuk egy hosszú élettartamú terméktípus esetében. A tanulmány további részében először ismertetjük a vizsgált értékláncot és annak lépéseit, majd vizsgáljuk az egyes lépésekben lehetséges minőség és elégedettség értelmezési és fejlesztési lehetőségeket. Végül összefoglaljuk föbb megállapításainkat.

\section{A vizsgált értéklánc}

Vizsgálataink során egy hosszú élettartammal rendelkező építőipari termékcsoport, a nyílászárók termelési-szolgáltatási értékláncát vizsgáltuk [5]. Az előbbi mondat elemei rávilágítanak arra, hogy a vizsgált értéklánc (1. ábra) számos sajátossággal bír. A fogyasztói piacon - például felújítási céllal - vásárolt nyílászárók mint termékek megvásárlása magával hozza az annak használatbavételéhez szükséges szakmai szolgáltatás (a beépítés) igénybevételét. Ehhez a két igencsak különböző értékteremtő lépésben szerzett elégedettségi szinthez járul a termék hosszú távú használatából adódó további elégedettség vagy épp elégedettlenség.
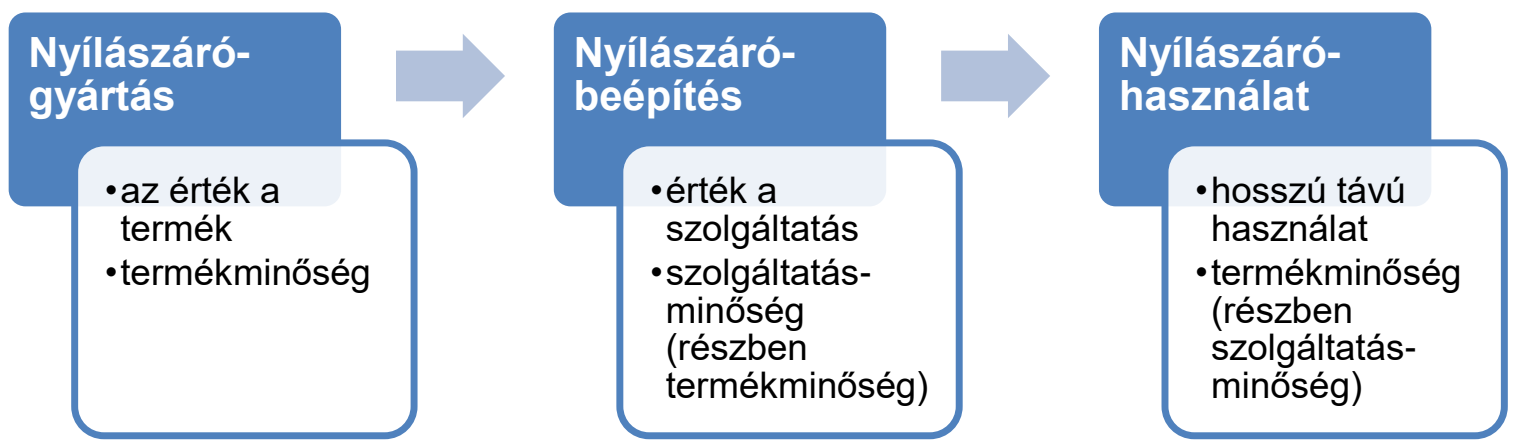

1. ábra. A vizsgált értéklánc

A vizsgált értékláncot az előállítástól a használatbavételen át a használati idő végéig eltelt idő (évtizedek) folyamatlépései alkotják. Ahhoz pedig, hogy gyártó és szolgáltató tevékenységet és eredményét tudjunk elemezni vevő elégedettség szempontjából, termék és szolgáltatás dimenziókat is vizsgálnunk kell [5]. Gyártó szervezetek esetében a termék dimenziók fognak nagyobb hatást gyakorolni, míg szolgáltatóknál magától értetődőden inkább a szolgáltatás dimenziók. Ugyanakkor termékek vásárlása esetén is lesznek szolgáltatás jellemzők, amelyek befolyásolják a végső vevői élményt és szolgáltatásoknál is számít, hogy milyenek a szolgáltatást övező tárgyi eszközök, a tárgyi környezet.

\subsection{Gyártás}

Egy nyílászártók gyártására szakosodott vállalkozás szakembereitől szerzett információk alapján a nyílászárók előállítása - fa, műanyag, vagy alumínium ablakról, ajtókról lévén szó - 
soklépéses és összetett folyamat. Mindhárom anyag esetében elmondható, hogy az ezekböl készült ablakok, ajtók gyártása az alapanyag beszerzésével kezdődik és a méretre vágás, megmunkálás, vasalatok szerelése, összeállítás után minőségellenőrzéssel ér véget.

A gyártásra konkrét példaként a költséghatékony és az erős hegesztési kötéssel rendelkező műanyag nyílászárók gyártását ismertetjük. Ennek során a műanyag ablakprofilok extrudálással készülnek. (A gyártásuk folyamán az alapanyaghoz többféle adalékanyagot adnak, melyeknek köszönhetően a müanyag nyílászárók évtizedeken keresztül stabilak és színtartók maradnak. Ellenállnak a külső és belső környezeti hatásoknak úgy, hogy közben alakjuk sem változik.) Ezeket a PVC profilokat, elemeket még a gyártás megkezdése előtt egyedi azonosítóval látják el. A teljes gyártási folyamat első lépéseként az elemet méretre kell vágni, meg kell munkálni és merevítő vasat kell belehelyezni, ezzel merevségét adva majd a toknak, és a szárnynak. A CNC marógép levágja a tokok és szárnyak oldalait és elvégzi a furatok felvitelét is. A méretreszabás során behajtókkal felcsavarozzák a tokok zárfogadóját. Ezt követi az automatizált gyártósoron a 4 oldal összehegesztése 4 pontos hegesztőgéppel. Majd a tokok szerelésre, a szárnyak vasalásra mennek tovább. A tokszerelés során kerülhet fel a tokosztó, illetve a redőnyözéshez szükséges toktoldó. $A z$ ablakszárnyak szerelésénél a vasalatokat szerelik fel, illetve felkerülnek a zárszerkezetek is. $A z$ összeillesztés során a tokok és a szárnyak párosítása, összeakasztása történik meg. Az üveg behelyezése a legutolsó fázis, amely során üvegszorító léccel 4 oldalról erősítik be az üveget. ( $A$ höszigetelt üvegtáblák: 2-3 rétegü üveg, rétegek közé töltött argongáz felel a hőszigetelésért.) Környezetünk tehermentesítése a műanyag hulladék kalodában való tárolása, műanyagfeldolgozó üzemeknek való továbbadása révén érhető el.

\subsection{Beépítés}

A nyílászárók használatbavétele azok (akár a korábbi nyílászáró bontásával egybekötött) beépítésével történik. Mivel ez a tevékenység szakértelmet kíván, a végfelhasználók jellemzően szakemberek segítségét veszik igénybe, tehát egy szolgáltatás eredményeként tudják használatba venni a terméket.

Egy ilyen folyamat jellemzően a következő tevékenységekböl áll [10] [13]:

1. Ablakgyártó vagy forgalmazó kiválasztása, felkeresése, ajánlatkérés

2. Helyszíni felmérés (egyeztetés a nyitásmódról, a kialakításról, az elhelyezkedésről), ezt követően a müanyag ablakprofilok legyártása, illetve kiszállítása.

3. Az ablak szakszerü beépítése:

3.a. A régi ablak kivágása, a falnyílások elökészítése, tisztítása.

3.b. A szárnyak leszerelése után következik a toktoldók felszerelése, valamint a tokfalnyílásba illesztése, szintezés.

3.c. A mủanyag ablak rögzítése - a rögzítővasak felszerelése a tokra.

3.d. A tok és a falnyílás közötti hézag kitöltése pur-habbal.

3.e. A szárnyak visszahelyezése, kilincs rögzítése.

4. A beépítés után az ablakot a teljes felületen a következő szakipari munkák szennyeződésétől megvédve védőfóliával le kell takarni, illetve a takarítási tevékenységeket el kell végezni.

\subsection{Használat}

A nyílászárók több évre, évtizedre kiterjedő használata során számos folyamat mentén formálódik a vevő érték. A hosszú távú használat során a termékgyártás kimenetének megtapasztalása és időbeli változása történik, a szolgáltatási folyamat hozzáadott értéke lassan elveszik ezen időszak alatt.

\section{Az érték és minöség értelmezése}

Minden szektor, így az építőipar számára is megvalósítandó feladat a minél teljesebb vevői elégedettség elérése, a minőség javítása. Minél több elnyerhető projekt, valamint a minél jobb ajánlások érdekében a szervezetek célja a jobb, erősebb és hosszabb kapcsolat kialakítása a vevőikkel. A vevői elégedettség fontossága és mérhetősége érdekében fontos a folyamat egyes lépéseiben rejlö értékteremtés meghatározása. 
A bemutatott ablakgyártási folyamatban található érték maga az ablak. Kézzel fogható termékröl lévén szó Garvin [4] nyolc termékdimenzióját érdemes alapul venni az érték felmérése és fejlesztése során. Ezek a teljesítmény, a különleges tulajdonságok, a megbízhatóság, a megfelelés, a tartósság, a szervizelhetőség, az esztétika, és a minőség észlelése. A minőségdimenziók nyílászárókra való értelmezését az 1. táblázat foglalja össze.

1. táblázat: A dimenziók és megjelenésük az ablakoknál

\begin{tabular}{|l|l|l|}
\hline & \multicolumn{1}{|c|}{ Termékdimenziók } & \multicolumn{1}{c|}{ Hogyan jelenik meg? } \\
\hline 1. & Teljesítmény & müködési jellegzetesség \\
\hline 2 & Különleges tulajdonságok & légáteresztés, vízzárás, szélállóság stb. \\
\hline 3. & Megbízhatóság & két karbantartás között eltelt átlagos idő \\
\hline 4. & Megfelelés & beépíthetőség, müködési jellemzők \\
\hline 5. & Tartósság & a föbb alkatrészek várható élettartama \\
\hline 6. & Szervizelhetőség & $\begin{array}{l}\text { elérhető szervizek száma, alkatrészek } \\
\text { cseréjének ideje }\end{array}$ \\
\hline 7. & Esztétika & $\begin{array}{l}\text { kinézet, belső, külső környezethez való } \\
\text { illeszkedés }\end{array}$ \\
\hline 8. & Minőség észlelése & $\begin{array}{l}\text { a márka hírneve az ablakgyártók } \\
\text { iparágában, a fogyasztók értékelése }\end{array}$ \\
\hline
\end{tabular}

A vevői elégedettség növelése érdekében a kielégítő ár-érték arány, a standardoknak való megfelelés, valamint a funkcionális megfelelőségen túl egyéb (például az 1. táblázatban látható) minőségdimenziókkal is növelni kell a termék színvonalát. És fontos figyelembe venni, hogy egy építési munka (elképzelés, tervezés, kivitelezés, átadás) során a minőség megléte a tervkészítés és a kivitelezés (minőségi alapanyag választása) során a legjelentősebb. Az ezzel kapcsolatosan felmerülő extra költségek a hosszabb élettartammal rendelkező alapanyagok, illetve az alacsonyabb felújítási költéségek révén később megtérülnek.

Továbbá, a nyílászárókra értelmezett minőségdimenziók gyártók általi számbavételekor legalább két nézőpontot fontos a gyártó vállalatoknak szem előtt tartaniuk. Egyrészt a szakemberek szakmai véleménye az, ami alapján terméküknek lehetősége van eljutni a végfelhasználóhoz - akár a közvetlen végfelhasználónak történő ajánlás, akár nagyobb projektekbe való bekerülés által. Másrészt a végfelhasználók a használat tapasztalatait elsősorban e dimenziók mentén ítélik meg, tehát fontos mérlegelni a (különleges szakmai tudás nélküli) gyakorlati tapasztalatokat is.

Az építőanyagipari termékek körüli termék-szolgáltatás rendszerek következtében megfigyelhető, hogy ebben az iparágban sem csak az anyagok minősége az, ami meghatározza a vevői elégedettséget, hanem a termékeket körülvevő szolgáltatás is befolyásolja a vevő által észlelt minőséget. A beépitést, mint kapcsolódó szolgáltatást Parasuraman és szerzőtársai 10 szolgáltatás dimenziója mentén érdemes vizsgálni [11]. Ezek a kategóriák: megbízhatóság, alkalmazkodóképesség, hozzáértés, hozzáférhetőség, udvariasság, kommunikáció, hitelesség, biztonság, vevő megértése, kézzel fogható tényezők. A minőségdimenziók beépítési szolgáltatásra való értelmezését a 2. táblázat foglalja össze. 
2. táblázat: A dimenziók és megjelenésük a kapcsolódó szolgáltatásnál

\begin{tabular}{|l|l|l|}
\hline & \multicolumn{1}{|c|}{ Szolgáltatásdimenzió } & \multicolumn{1}{|c|}{ Hogyan jelenik meg? } \\
\hline 1. & Megbízhatóság & $\begin{array}{l}\text { a beépítő ajánlata által az ügyfél } \\
\text { bizalmának elérése }\end{array}$ \\
\hline 2. & Alkalmazkodóképesség & $\begin{array}{l}\text { a beépítő hozzáértése a szolgáltatás } \\
\text { nyújtásához }\end{array}$ \\
\hline 3. & Hozzáértés & $\begin{array}{l}\text { az ajánláshoz szükséges jártasságok és } \\
\text { tudás }\end{array}$ \\
\hline 4. & Hozzáférhetöség & $\begin{array}{l}\text { az építőanyag kiválasztásában adott } \\
\text { segítség }\end{array}$ \\
\hline 5. & Udvariasság & a beépítő viselkedése, figyelmessége \\
\hline 6. & Kommunikáció & $\begin{array}{l}\text { hasznos információk, a használt } \\
\text { nyelvezet }\end{array}$ \\
\hline 7. & Hitelesség & a cég hírneve \\
\hline 8. & Biztonság & fizikai, pénzügyi biztonság \\
\hline 9. & Vevő megértése & a vevő igényeinek felmérése \\
\hline 10. & Kézzelfogható tényezők & $\begin{array}{l}\text { a szolgáltatás nyújtásához használt } \\
\text { szerszámok és berendezések }\end{array}$ \\
\hline
\end{tabular}

A kapott szolgáltatás minőségéröl kialakult kép a szolgáltatás funkcionális megfelelőségén messze túlmutat (például a 2. táblázatban látható tényezők mentén), és az elégedettségi szintet számost szubjektív tényező (az észlelés és érzékelés kognitív tényezői, az érzelemelméleti tényezők stb.) is befolyásolja. Ráadásul a nyújtott szolgáltatás egyes minőségdimenziók mentén való megítélését árnyalják a választott (ajánlott) termék jellemzői is. A végső vevői érték meghatározásánál tehát a 10+8 dimenzió megítélése történik, egymástól nem is függetlenül.

A nyílászárók hosszú élettartamú használata során ismét a termék megfelelősége, annak egyes használati jellemzői kerülnek a vevői érték középpontjába. A vevőnek hosszú évek állnak rendelkezésére, hogy megismerje a termék legföbb dimenziókban (elsősorban a légáteresztés, vízzárás, szélállóság, hőszigetelés, léghanggátlás, tartósság stb. területén) nyújtott teljesítményét, sőt akár azok változásait. A használat során tehát a vevőben nem egyszeri észlelés alakul ki a termékröl, előjöhetnek/előjönnek problémák is. A használatból adódó érték ráadásul egyéb tevékenységekkel (például további szigetelési munkálatok) növelhetök.

A termékek és szolgáltatások megvásárlását követően és hosszú távú használata során fellépő vevői elégedettségre és értékre hatást gyakorló tényezők vizsgálatával több tudományterület foglalkozik, különböző megközelítésekben:

- A marketingmenedzsment a vásárlás utáni magatartás vizsgálatakor nagy hangsúlyt fektet kognitív disszonancia csökkentésének lehetőségeire [1]. Fontos kiemelni, hogy a vizsgált esetben minimálisan két vásárlási döntést mérlegelnek a vevők: egy termékre és egy szolgáltatásra vonatkozót.

- A termék minőségi jellemzőinek használati idő alatti változásait és befolyásolási lehetőségeit a megbízhatóságelméletre támaszkodó minőségmenedzsment megoldások támogatják [8]. A termékek természetes öregedési folyamatából származó meghibásodások negatív hatásai megfelelő megelőző tevékenységekkel jól kompenzálhatók.

- A tényleges termékhasználat során a termékhasználat ergonómiai használhatóság fogalmába tartozó dimenziói - biztonság, hatékonyság, kényelem - mentén vizsgálhatók [6]. Ezekre a tényezőkre - a korábbi példákban szereplö tényezökhöz hasonlóan - természetesen már a termék- és szolgáltatástervezés szakaszában is figyelemmel kell lenni, még ha tényleges megtapasztalásuk csak a használat során történik is meg. 


\section{4. Összefoglalás}

A termelési-szolgáltatási értékláncok előnyeit számos kutatás vizsgálta és számos gyakorlati szakember tapasztalta meg. A szolgáltatások magas terméktartalma vagy a termelő vállalatok szolgáltatói tevékenységei mind arra felismerésre épülnek, hogy a vevői értékteremtés e két formája fontos pozitív szinergiákat hordoz magában.

A nyílászárókat, mint termékeket életciklusuk során szolgáltatások veszik körül, éppen ezért a minőség és vevői elégedettség dimenzióinak feltárásához elengedhetetlen a termelés és szolgáltatás jellemzőinek, a termékek és szolgáltatások minőségdimenzióinak összekapcsolt vizsgálata. A szolgáltatási tevékenység fontos része a termékkel kapcsolatos tanácsadás, mivel a vevő (felhasználó, megrendelö) nem minden esetben van tisztában az építőanyagok különböző jellemzőivel. És mivel a szolgáltató ajánl/választ terméket, a szolgáltatás minőségének megítélése elválaszthatatlanná válik a termékminőségtől. Ráadásul az, hogy az ajánlott termék minősége mennyire megfelelö, csak a használat során derül ki.

A vizsgált értéklánc áttekintése során láthattuk azt is, hogy nem csupán a kétféle értéklánc integrálásáról van szó, az értékfolyam nem áll meg az érintett vállalatok határain, a használat számos jellemzője és sokszor maga a végfelhasználó tevékenysége (legyen az saját tevékenység vagy újabb szolgáltatás, termék vásárlása) is adhat szolgáltatást a termékhez.

Mindezek mentén egyértelmüen kirajzolódik, hogy egy átfogó szemléletü, értékláncban gondolkodó termelővállalatnak és a vele (remélhetőleg partneri) kapcsolatban álló szolgáltatóknak a minőséget két (termék és szolgáltatás) oldalról kell megközelíteniük, és mindkét esetben olyan kulcsfontosságú teljesítmény mérőszámokat (KPI-ok csoportjait) kell meghatározniuk, melyek mentén a minőség mérhetővé válik, és ezáltal könnyen visszacsatolható a szervezeti müködésbe. Ha pedig sikerül ezek mellé megragadni a vevők teljes élethosszig tartó értékét is, akkor a tevékenységükkel a felhasználás fázisának értékteremtésére is hatással tudnak lenni.

\section{Irodalomjegyzék}

[1] Bernschütz M., Bíró-Szigeti Sz., Danó Gy., Józsa L., Kalló N., Kovács I., Kövesi J., Magyar M., Mandják T., Pataki B., Petruska I., Topár J., Tóth Zs. E., Veres I.: Marketing: Fókuszban a termék, Typotex, Budapest, 2017

[2] Chikán A.: Vállalkozásgazdaságtan. Aula Kiadó, 2004.

[3] Chikán A., Demeter K. (szerk.): Az értékteremtő folyamatok menedzsmentje. Termelés, szolgáltatás, logisztika. Aula Kiadó, Budapesti Közgazdaságtudományi Egyetem, 1999.

[4] Garvin, D.A.: Competing on the eight dimensions of quality. Harwards Business Review, 1987, 65. évf. 6. szám, pp. 101-9.

[5] Gerse-Krizsa T., Surman V.: Vevőközpontúság az építőanyag-iparban. In: Horváth B., Kápolnai Zs., Földi P.(szerk): Közgazdász Doktoranduszok és Kutatók V. Nemzetközi Téli Konferenciája Konferenciakötet, 2019, p. 246-253.

[6] Hercegfi K., Izsó L. (szerk.): Ergonómia. Typotex, Budapest, 2008.

[7] Kövesi J., Topár J. (szerk.): A minőségmenedzsment alapjai. Typotex, Budapest, 2006.

[8] Kövesi J. (szerk.): Minőség és megbízhatóság a menedzsmentben. Typotex, Budapest, 2011.

[9] Neely, A.: Exploring the financial consequences of the servitization of manufacturing. Operations Management Research, 2008 1: (1) 103-118.

[10] Németh Nyílászáró Gyártó és Forgalmazó Kft. Beépítési útmutató műanyag nyílászárókhoz. Letöltés dátuma: 2020. december 7, forrás: Webhely neve: https://www.nemethkft.hu/files/beepitesi_utmutato_muanyag_nyilaszarokhoz.pdf

[11] Parasuraman, A., Zeithaml, V. A., Berry, L. L.: A Conceptual Model of Service Quality and Its Implications for Future Research. Journal of Marketing, 1985, 49. évf. szám, pp. 41-50. https://doi.org/10.2307/1251430

[12] Porter, M. E.: Competitive advantage: creating and sustaining superior performance. The Free Press, New York, 1985.

[13] VEKA Csoport. (2020.08.07.). A müanyag ablak szakszerü beépítése - a szakember válaszol - VEKA Magyarország. Letöltés dátuma: 2020. december 7, forrás: Webhely neve: https://veka.hu/a-muanyag-ablakszakszeru-beepitese/

[14] Womack, J. P., Jones, D. T.: Lean szemlélet - A veszteségmentes, jól működő vállalat alapja. HVG Kiadó, Budapest, 2009. 